\title{
Star Trek tietoyhteiskunnan syövereihin
}

\author{
Raivola, R. \& Vuorensyrjä, \\ M. (1998) O saaminen \\ tietoyhteiskunnassa. \\ Helsinki: Sitran raportti no. \\ 180. $94 \mathrm{~s}$.
}

$\mathrm{T}$

ässä tietoyhteiskuntastrategian kansallista uudistamishanketta tukevassa teemaselvityksessä Tampereen tähtiakatemian tutkijat, Reijo Raivola ja Matti Vuorensyrjä aikahyppäävät tulevaan tietoyhteiskuntaan ja luotaavat osaamisen ja oppimisen asemaa siinä. H eidän raporttinsa paljastaa outoja käsiteolioita, ennennäkemättömiä organisaatiomuotoja ja antaa olettaa, että uusi tietointensiivisempi sivilisaatio toimii mahdollisesti perustavalla tavalla toisin kuin aikaisemmat. Sitä vastoin koulutus näyttäisi jo nykysuuntauksissaan asettuneen tukevasti radalle kohti tietoyhteiskuntaa.

Tetoyhteiskunnan keskeisenä
energialähteenä on hiljaisen
tiedon vapauttaminen ja valjas-
taminen huippuosaamisen tuo-
tantoon. Tällaisen osaamisen ja
asiantuntijuuden kehittyminen
vaatii aikaa määrättömästi - kon-
struktiivisen oppimiskäsityksen
mukaan vuosien ellei peräti vuo-
sikymmenten kokemuksellista
harjaantumista johonkin. K es-
keisessä roolissa on toimijayh-
teisö. Siinä yksilön hiljaisesta tie-
dosta voi tulla yhteisöllisten in-
novaatioiden lähde. Yksittäisen
työntekijän itsenäinen osaaminen
ja oppiminen on innovaation ja
tiedon konstruoinnin siemen.
Ajateltava syntyy dialogin ja kanssakäymisen kautta. Tietotaloudessa asema määräytyy ydinosaamisen ja oppimiskyvyn koordinaatein. A semointi edelIyttääkin tiedon ja ydinosaamisen muodostumis-, tunnistamisja kehittämismekanismien hallintaa.

$\mathrm{H}$ uippuosaaminen muodostuu pitkälle harjaantuneiden tietoammattilaisten klusterispesifissä tutkimuksessa ja klusterispesifeissä käytänteissä. Verkostotalouden arkkitehtuurin kielelle käännettynä tämä tarkoittaa Raivolan ja Vuorensyrjän mukaan yleistä sekä klusterispesifiä inhimillistä pääomaa. $\mathrm{He}$ luonnehtivat sekä tulevan sivilisaation yrityksiin että yrittäjiin kohdistuvia vaatimuksia analyyttisesti, empiirisesti ja ohjelmallisesti otettuina kompetenssikuvauksina. H enkilöstöluettelossa vilahtavat sellaiset nimikkeet, kuten tietointensiivisen talouden symbolianalyytikko ja erikoistunut generalisti.

Jos vielä tunnet oppivasi, jos sinuun edelleen investoidaan, jos voittaisit oman toimesi uudessa haussa milloin vain, jos olet lähes korvaamaton, jos istut verkkojen solmu- tai päätekohdissa ja jos elät symbioosissa asiakkaasi kanssa, olet oikeaa ainesta tietoyhteiskunnan eliittiin. Tietoyhteiskunnassakaan kaikki tehtävät eivät vaadi korkeaa osaamistasoa. K irjoittajat kääntävät korkea osaamistason yksinkertaiseksi, mutta kaksiteräiseksi kriteeriksi: oletko omassa työssäsi helposti korvattavissa toisella henkilöllä vai pyritäänkö sinut sitouttamaan yrityksen omistajuuteen osakkuuden tai optioiden avulla - omistavaan ryhmään kuuluminen ei ole haitta tietoyhteiskunnassakaan.

Uusi sivilisaatio kaipaa ydinosaamistasi, joten tunnista se, kehitä ja hyödynnä sitä. Kysymys on jalostusverkon kaipaamasta kontribuutiosta, jonka sinä olet maailman paras toimittamaan. K eksi siis mitä tahansa, jonka kaikki muut tai edes joku haluaa hankkia vain juuri sinulta. Pääomaasi ovat tuotannollisesti relevantit ominaispiirteesi. K irjoittajien mukaan on koko joukko syitä - niin kokemuksen kuin järjenkin tuottamia - olettaa, että kompetenssien ja niiden yhdistelmien arvo syntyy suurimmaksi osaksi vasta työelämässä. 0 saava inminen, työntekijä tietoineen, taitoineen ja oivalluksineen, on osaamistihentymä, joka painaa globaalissa jalostuverkossa enemmän kuin mikään toinen osaamistihentymä. Y ksittäisen työntekijän painoarvo määräytyy kuitenkin siitä, miten voimakkaasti hän vetää jotakin jalostusverkkoa puoleensa. $\mathrm{Ne}$, joista ei löydy minkäänlaista vetovoimaa, ovat kykenemättömiä telakoitumaan tietoyhteiskunnan Selbstschaftiin ja toteuttamaan oman identiteettinsä mukaisia päämääriä. Jalostusjärjestelmään telakoitumattomilla ei ole omaa kurssia.
$\Lambda$ rgonauttimme myöntävät sosiaalisen koheesion heik- kenemisen mahdollisuuden. Sirpaleyhteiskunnassa valtautu- minen vaatii kiinnittymistä ja 
monipuolinen kiinnittyminen moninaisia liittimiä. M arkkinaavaruudessa, jossa tavarat, ideat, työvoima jne. liikkuvat vapaasti, parhaiten menestyvät ne, jotka ymmärtävät siihen sisältyvän vapaudettomuuden (markkinamekanismi) ja jotka osaavat laatia omat strategiansa sen mukaisesti. K irjoittajat tosin huomauttavat, ettei nykyinen käsityksemme ko. mekanismista ole välttämättä pätevä uudessa tietopitoisessa ympäristössä.

K ontekstin vaihdoksiin valmiiden tietoyhteiskuntalaisten imuohjatut kontribuutiot järjestyvät plugin yhtiöinä, virtuaali- tai irrationaalisina yrityksinä, kolmiulotteisina, hypertekstuaalisina, transkendentteina tai kuvitteellisina organisaatioina ja useina verkostuneina satelliittiyhtiöinä. D igitaalisessa asiakasorientaatiossa tuotanto tapahtuu vuoropuheluna asiakkaan kanssa. K un asiakkaalle tarjoutuu tilaisuus pohtia yhdessä tuottajan kanssa, mitä hän oikeastaan haIuaa tuotteelta, avautuu kirjoittajien mielestä tähtitieteellisiä mahdollisuuksia hintatehokkuuden parantamiseen.
Jotta markkinavaihdon välineet löytyisivät aina siitä taskusta, missä niiden optimaalisessa markkinatilanteen alla itseasiassa kuuluisikin olla, aineettomat varallisuuden lajit tulisi kyetä tunnistamaan ja mittaamaan aikaisempaa paremmin. 0 saamispääoman moderneimmatkaan luotaimet eivät nykyisellään täyttäne tehtäväänsä, kirjoittajat toteavat. Heidän mukaansa yrityksen markkina-arvolla ei ole muuta määräytymisen lähdettä kuin sijoittajien ja asiakkaiden arvonmäärityskriteerit. Selvityksen mukaan on tosiasia, että tuottajan teknologinen osaaminen sekä tuotteiden potentiaalisten hankkijoiden arvoarvostelmat syntyvät teknologisen kehittelyn, tuotekehittelyn ja markkinavaihdannan partikulariassa. Se puolestaan on vain vaikeasti luodattavissa ellei kokonaan luotauksen ulottumattomissa.

$\mathrm{K}$ irjoittajat nostavat johtopäätöksissään esiin $\mathrm{mm}$. elinikäisen oppimisen ja eettisen osaamisen roolin. Tuotantojärjestelmään telakoitumisen perusta luodaan muodollisella peruskoulutuksella. N äiden kah- den välistä avaruutta onkin täytettävä, mobilisoitava täydennyskoulutettavien massat, tarvittaessa muunto- ja siirtokoulutettava heitä, seurattava tarkemmin osaamispääomaa ja sen liikkeitä niin kansakunnan kuin yritystenkin tasolla ja pidettävä siitä huolta kokonaisvaltaisesti $\mathrm{mm}$. ulottamalla koulumobilisaatio kuusivuotiaisiin. 0 saaminen tietoyhteiskunnassa -raportti tarjoilee yhtäältä lennokasta, jopa paatoksellista varmuutta ja tähtitieteellisiä vaatimuksia. Toisaalta sen riveillä tuodaan esiin eri aspektien moninaisuus sekä joukko varjopuolia harkittuina, osuvina ja suorapuheisina synteeseinä. A ikaansaannoksella on arvoa ja tekijöillä kompetenssia, mikäli raportista on kontribuutioksi tiedontuotannon jalostusjärjestelmässä. Varmaan on ainoastaan se, että tässäkin suhteessa "[j]atkossa kontribuutio maailmanlaajuisesti kilpailtuun älykkäiden tuotantotekijöiden ja asiakasorientoituneiden hyödykkeiden ja palveluiden verkkoon on yhä suuremman työn, tuskan ja osaamispääoman takana" (s. 2).

\section{Vesa Huotari}

